\title{
HISTORIC RECURRENCE IN ARCHITECTURE FROM ANTIQUITY TO REFORMATION
}

\author{
Ravindra Patnayaka ${ }^{1}$, Suryakala Nannapaneni ${ }^{2}$ \\ ${ }^{1}$ Assistant Professor, GITAM School of Architecture, GITAM University, Andhra Pradesh, India \\ ${ }^{2}$ Assistant Professor, GITAM School of Architecture, GITAM University, Andhra Pradesh, India
}

\begin{abstract}
History acts as a facilitator in experiencing the past virtually, decoding the myths, troubleshooting the unsolved mysteries, unveiling the souvenirs, revealing the ekistics, etc. Architectural history in particular, explains the extrusion and morphology of built environment and its surroundings with respect to socio, cultural, economical, political, environmental, technological concerns and many more. Success will not come without failure; History of Architecture has initiated and shaped many concepts, construction mechanisms, etc. as a result of various pros and cons in design alternatives, learning from the many inevitable results and hence pioneered us to proceed further towards the next level instead of starting from the evolution. It played an important role in contributing the strategic balance between aesthetics and structural components right from our ancient past. History with its metamorphosis inspired and motivated the designers at various levels, and has become a renewable resource quotient in exploring new configurations based on the then existing examples. It left everyone with extreme knowledge, innovative mathematical implications, strategic construction techniques, creative concepts, etc. that can be made adaptable in contemporary times and resulted in designing prototypical iconic forms. This paper focuses on exemplifying certain contributions from the history and their influence in present-day conceptions. Also, discusses about the technological improvisations with time, and concludes with the anticipation that history never hinders progress and will continue to inspire the future generation architects and engineers hence forth.
\end{abstract}

Key Words: Architectural History, influence of history, construction techniques, aesthetics, Historic recurrence.

\section{INTRODUCTION}

"To provide meaningful architecture is not to parody history but to articulate it. ”Daniel Libeskind [1]

"Architecture should speak of its time and place, but yearn for timelessness ”Frank Gehry [2]

History of architecture is the study of changes in architectural buildings that influenced through diverse traditions, religions, socio-cultural aspects of various regions and periods that evolved over centuries and continues to change even today [3]. Ancient monumental buildings provide an insight into the history of architecture. The world we live-in is changing constantly, so, upgradation is involved in every stream of industry including architecture. Architects have designed many buildings with significant innovation in designs with good lifespan. Although some specific professional expertise such as conservation architects, archeologists etc., are commissioned to take utmost care and preserve such timeless wealth of our history, it is now a challenge to cushion their existence due to the rapid urbanization and conventional climatic change. This gave rise to a new concept 'Historic recurrence in architecture' which is the repetition of the similar building designs and concepts inspired from history [4]. This recurrence takes place due to certain discoverable situations and concatenations of reasoning.

\section{MESOPOTAMIAN INFLUENCE}

\subsection{Hanging gardens of Babylon to Green roofs in} buildings.

Hanging gardens located in the city of Babylon [Fig-1A: [5]] constitutes high walkways supported by stone pillars with all sorts of trees planted over a roof which had a layer of reed laid in bitumen and two courses of baked brick bonded by cement including a third layer of lead upon which earth had been piled to a depth sufficient for the roots of the largest trees frequently irrigated by machines raising the water in great abundance from the river [6]. Inspired from this we have a contemporary concept, Green roof [Fig1B: [7]] that consist of vegetation planted over a waterproofing membrane and different layers such as a root barrier, drainage and irrigation systems depending on the respective designs.
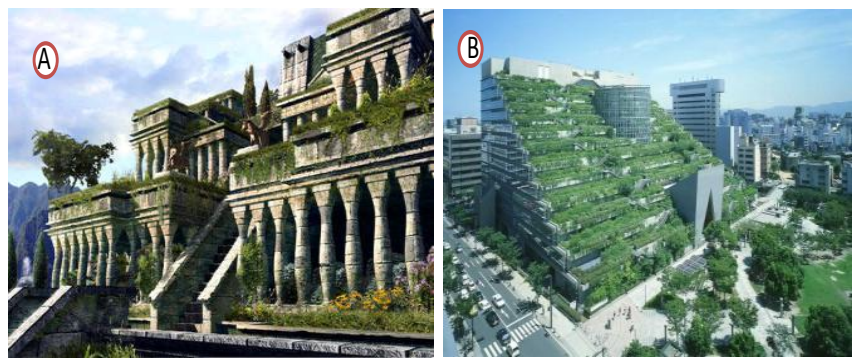

Fig -1: Roof Gardens 
This concept of integrating landscape within the building serves several purposes for a building, such as rainwater harvesting, intensifying insulation, recreating a habitat for disturbed endangered species like sparrows, squirrels etc., increasing benevolence and decreasing stress of the inhabitants, providing a cool roof [8] without compromising on the aesthetic appearance of the structure, lowering the ambient urban air temperatures and optimizing the heat island effect.

\subsection{Age Old Towers to High-Rise Structures}

Towers were constructed since pre-historic times as a symbol of escalator to reach good heavens. They were considered as materialistic structures to communicate with gods, a sign of victory, a symbol of pride and grandeur, an iconic focal element, a defensive vertical member to obtain a better view of the surroundings, etc. [9]. The ancient Tower of Babel [Fig 2A: [10]] stands as an inspiration to many high-rise structures built hence-forth and a clear morphology can be observed over the ages.

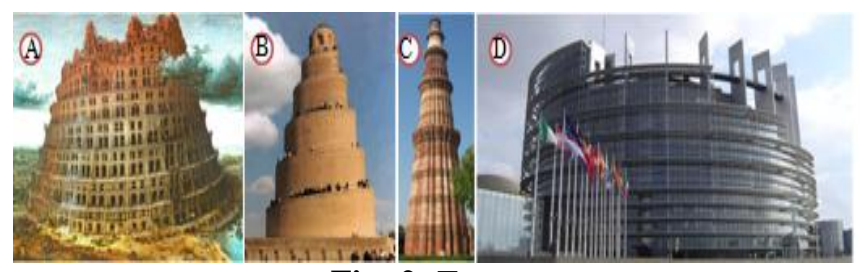

Fig -2: Towers

This transition can be seen in the Tower of Samara (Fig 2B: [11], Qutb Minar (Fig 2C.: [12], European Union building at Strasbourg-France (Fig 2D: [13] and many other modern skyscrapers [14].

\subsection{Ziggurats to Theme Parks Or Iconic Corporate Buildings}

Ziggurats were the temple forms built by Sumerians, Babylonians, Elamites, Akkadians and Assyrians of the ancient Mesopotamian civilization. They were planned within a temple complex as huge-stepped structures raised high above the ground ranged from two to seven storey's high and served many purposes; provided security from floods or spy's, satisfied as a religious or civic center and behaved as a nuclei for urban growth as settlements were often established around them [15].

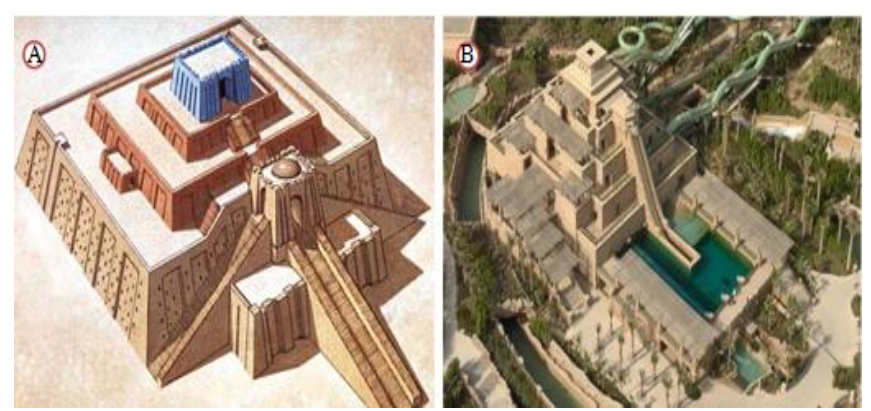

Fig -3: Ziggurats
The Mesopotamian ziggurat [Fig 3A: [16]] from the 6th century BC was a pyramidal flat-topped structure in receding tiers upon a square platform accessed by a series of ramps on one side, that acts as a prototype for the Aquaventure resort [Fig 3B: [17]] on the edge of the manmade island of the Palm Beach, Dubai which was constructed for recreational purpose of the visitors providing spectacular vistas from various levels of the structure [18].

\section{EGYPTIAN INFLUENCE}

\subsection{Ancient Pyramids to Innovative Pyramid City}

Pyramids are the most stable shapes for high-rise structures as they have a consistent low center of gravity and the shape naturally occurs in nature as a static form for sediment to build up in the form of mounds [19]. Mesopotamians built the earliest Pyramids known as a Mastaba, known for its monumental scale and massiveness by considering the then concept of most stable build ever existed, a heap form with outward sloping sides; and Egyptians refined it into geometrically perfect triangular structures that converge to a single point at the apex [20].

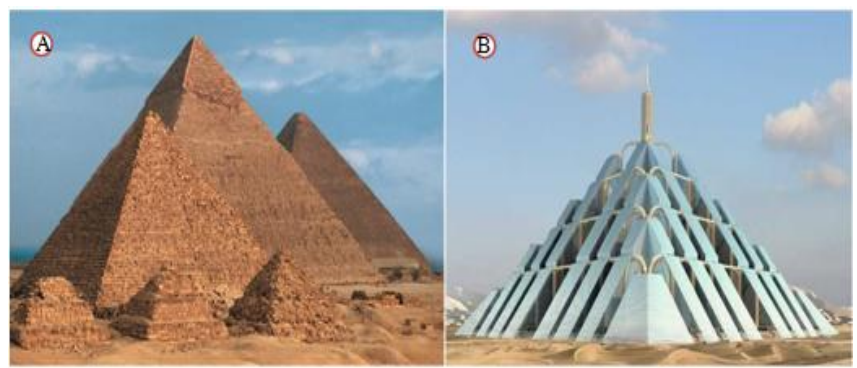

Fig -4: Pyramids

These forms were further developed into skyscrapers such as Empire State Building, the Eiffel tower, etc. For example, the Great Pyramids of Giza [Fig 4A: [21]] were built on a rocky plateau on the west bank of the river Nile in northern Egypt, interconnected by covered causeways. A contemporary example for this is the conceptual proposal of a Ziggurat pyramid-shaped arcology [Fig 4B: [22]] [23] which is defined as an ideal integrated city contained within a massive vertical structure, allowing maximum conservation of the surrounding environment, Dubai, designed as a gigantic envelope for a huge township to house one-million inhabitants in a self-sustainable community with renewable energy sources such as- wind turbine, solar energy, etc.

\section{GREEK INFLUENCE}

\subsection{Optical illusions and Optical corrections from}

\section{history to present}

Optical illusions are visually perceived images that differ from the reality i.e. the visual image captured by the eye is transferred to the brain that gives a perception which contradicts the existing structure [24]. Optical corrections are alternations to planes or surfaces to correct possible perceptions of distortion. The Greeks introduced and 
corrected these optical illusions in the temple of Parthenon [Fig 5A: [25]] on the Athenian Acropolis, Greece. In order to do this, in the Entasis- the height of stone courses was increased with the height of a wall so that the courses appear identical in height and the stylobate is given a slight convex surface, and in the columns- the central part of the shaft was slightly made wider than the top.

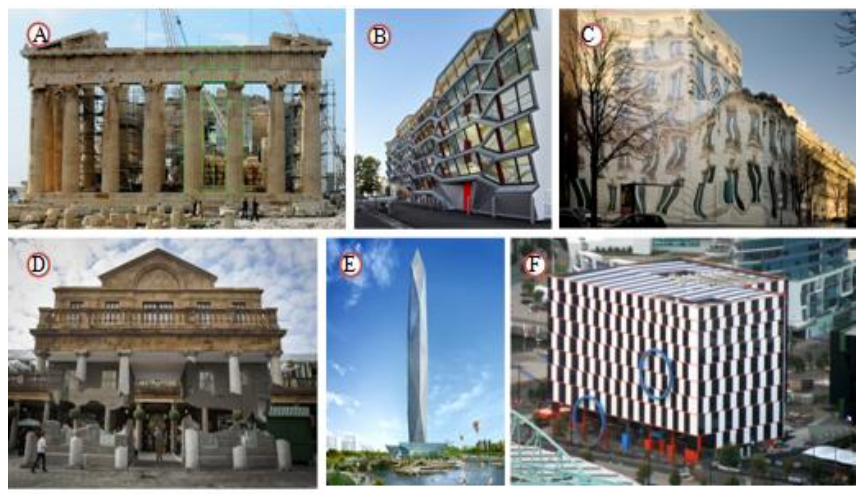

Fig -5: Optical illusions and corrections

Further experiments were carried forth and several illusions were created. Few examples include the warped buildings, deformed landscapes, collapsing illusion in Lyons Warrnambool campus building [Fig 5B: [26]] melting murals in the facades [Fig 5C: [27]], buildings floating in air [Fig 5D: [28]], infinity tower [Fig 5E: [29]], wall illusion of Café at Melbourne [Fig 5F: [30]], etc.

\subsection{Ancient Amphitheatres to Stadia}

Amphitheatre is an open-air venue used for entertainment, performances, or sports. It may be elliptical, semi-circular or circular in plan with seating tiers surrounding the central performance area [31]. Ancient Roman amphitheatres such as the Colosseum [Fig 6A: [32]], built in the city centre of Rome, Italy, served as major public venues, used for events such as gladiator combats, chariot races, animal slayings, executions, etc. This can be seen as an inspiration for many outdoor sporting venues, especially stadiums, concerts, or others that allow spectators to sit and view the events.

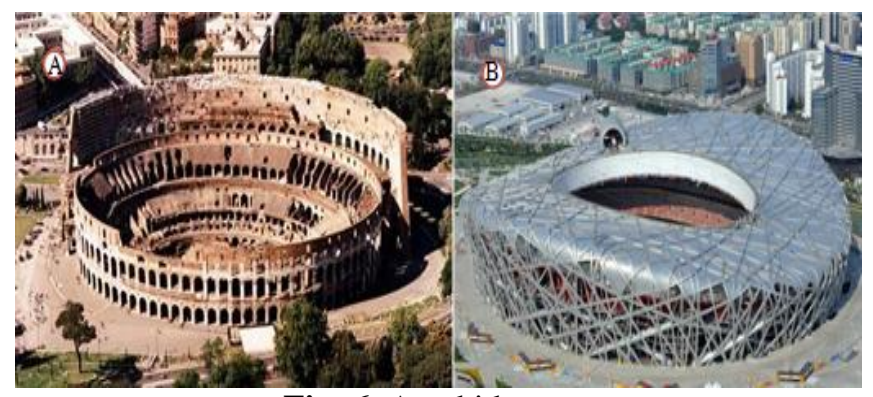

Fig -6: Amphitheaters

Contemporary amphitheatres include bandshells, either curved or bowl-shaped to amplify sound making it ideal for musical or theatrical performances. The modern stadia's [Fig 6B: [33]] are of multiple use designs that combine a football pitch with a running track, seating for the audience and other services.

\section{MEDIEVAL INFLUENECE}

\subsection{Gothic Architecture As A Prototype To Modern Church Buildings}

Gothic style, contributed the most successful structural systems effectively engineered with uncompromised aesthetics as well as ornamentation rather than intensifying the beauty of the whole structure itself; [34] such as, pointed arches, ribbed vaults, flying buttresses, etc that has become a profound prototype for every church, cathedral or civic building being constructed across the globe even today.

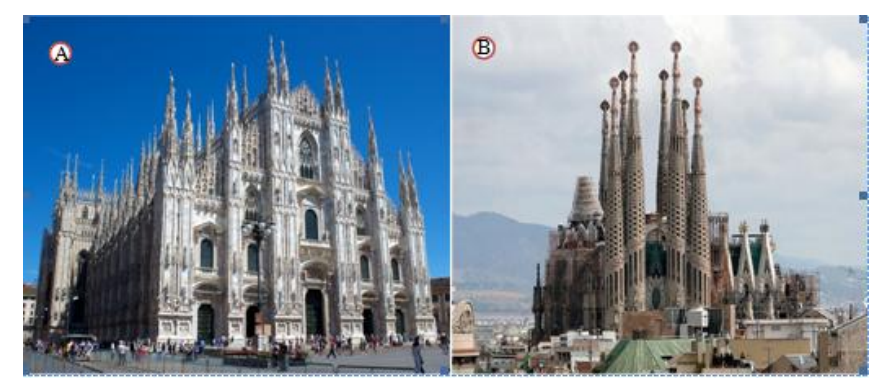

Fig -7: Cathedrals

Catalan architect Antonio Gaudi having inspired from Gothic Cathedrals [Fig 7A: [35]] and Art Nouveau forms, used curvilinear forms of natural organic forms in the Basilica I Temple Expiatori de la Sagrada Familia [Fig 7B: [36]]. This can set as a good contemporary morph of the Gothic architecture.

\section{INFUENCIAL ELEMENTS AND CONCEPTS FROM HISTORY}

\subsection{Emphasizing The Entries For Vicinities}

Pylons are tall tower-like structures or monumental gateways, built of stone or brick, used as an entrance ways to sacred areas or cities since historic times. They consist of two tapering or trapezoidal towers, each surmounted by a cornice, joined by a less elevated section that encloses the lower height entrance placed between them [37]. This element was introduced by the Babylonians as the Ishtar Gate [Fig 8A: [38]], the main entrance to the city of Babylon. Egyptians used Pylons [Fig 8B: [39]] in the form of foreshortened pyramids to mark the entrances of tombs and included ornamentation with scenes emphasizing the Pharoah's authority; both Classical and Egyptian revival employed these for bridge buildings.

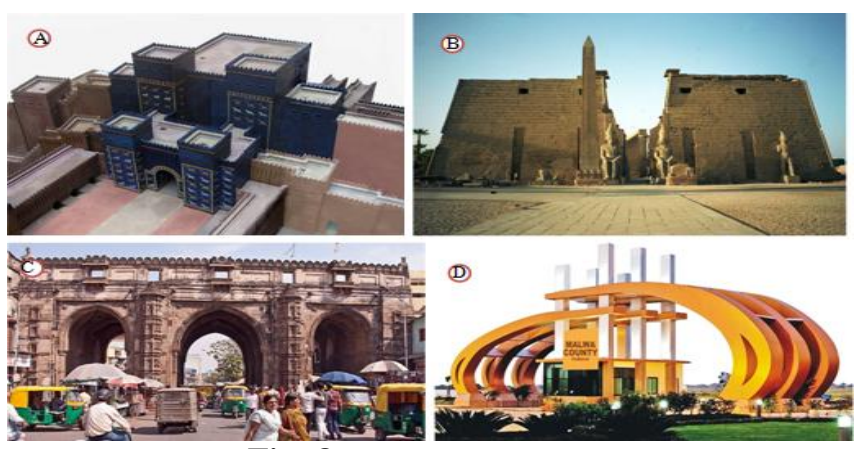

Fig -8: Entrance gateways 
Mughals used the Pylons as entrance gateways for palaces or forts [Fig 8C: [40]. The modern use of this in architecture is seen in gated communities [Fig 8D: [41]] or any restricted campuses that have controlled entrances for pedestrians, bicycles and automobiles within a closed perimeter of walls and fences.

\subsection{Emphasizing The Entries For Buildings}

Portico or porch is an extended roof leading to the entrance of any building supported by a colonnade or located over a walkway or enclosed by walls to protect from weather. Ancient porticos served as a long, open structure accommodating shops and delineating public squares from the original city [42]. The origin of Porticos can be known from the Hellenistic period, 3rd-1st century B.C. during the ancient Greek civilization and is a principal feature of Greek temple architecture as the types of portico furnish the main typology- amphiprostyle (porticos both in front and in back), peripteral (colonnade completely around it), etc. For example, the Parthenon at Athens would be described as hexastyle (six-columned) peripteral.

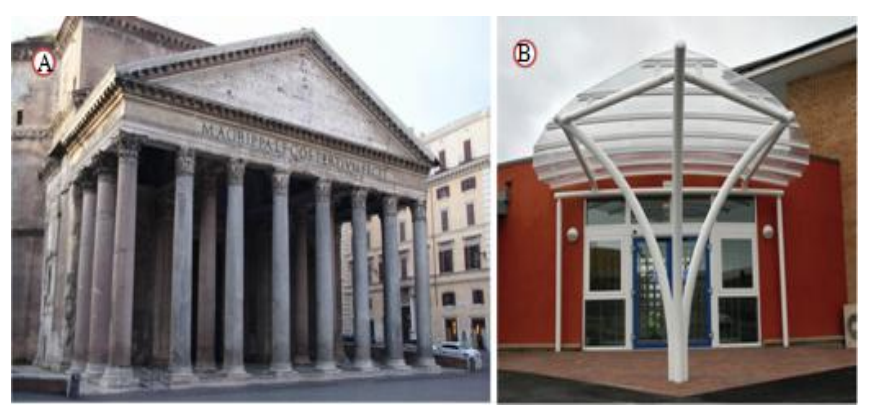

Fig -9: Pylons and canopies

The entrance portico of Pantheon [Fig 9A: [43]], a large granite Corinthian colonnade surmounted by a pediment, was a prominent element in Roman architecture [44] inspired structures ever since. Canopy [Fig 9B: [45]] is a contemporary version of portico that is supported by the building to which it is attached or by means of few upright stanchions or can also stand alone, covered with fabric gazebo's that are long-lasting, bright, easily cleaned, strong and flame-retardant [46].

\subsection{Golden Ratio In Architecture From History To \\ Present}

Golden ratio is a special number found by dividing a line into two parts such that the longer part divided by the smaller part is equal to the whole length divided by the longer part. It is also referred to as the Golden Rectangle, the Golden Section, the Divine Proportion, and Phi $(\varnothing=1.618)$ [47]. This system of proportions was used in the construction of many historical structures, for instance, in the Parthenon- it was used in the rectangular floor plan [Fig 10A: [48]] and the exterior dimensions of the façade [Fig 10B: [48]], in the Great Pyramids of Giza [Fig 10C: [49]] [Fig 10D: [50]] - it was represented as the ratio of the length or height of the triangular face to half the length of the square base, in the Notre Dame De Paris [Fig 10E: [51]] - it was used in the west façade of the Gothic Cathedral, in the complete structure of the Ryugyong Hotel-North Korea [Fig 10F: [52]].

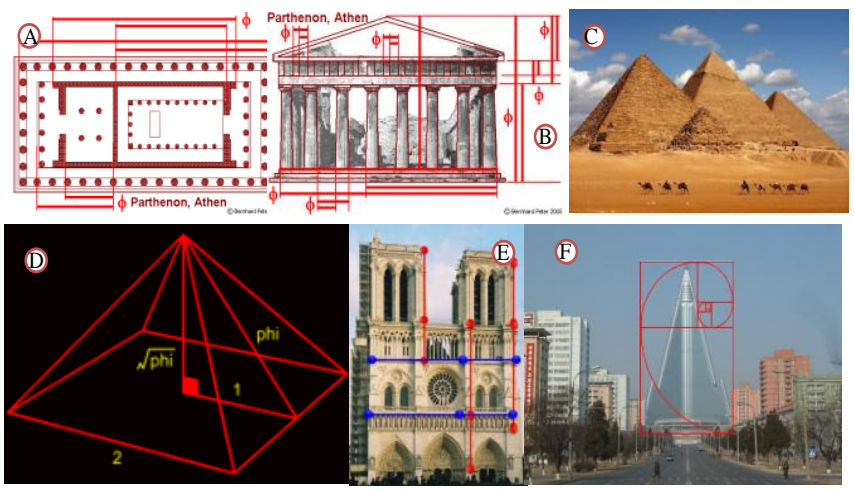

Fig -10: Golden ratio in architecture

The Golden Ratio is also associated with the Vitruvian Man, Pythagorean theorems, Fibonacci series, Le Corbusier's Modular series, paintings during De Stijl movement, etc. [53]

\subsection{Façade Treatments- From Cladding To Biomorphic Architecture}

Façade is any exterior face of a building which is the most important aesthetic aspect from a design standpoint, as it sets the tone for the rest of the building [54]. Cladding of buildings is an important and commonly applied activity area of building sector that separates the indoor environment from the outdoors suitable for the buildings intended use [55]. Historically speaking, large openings were initiated in the gothic architecture. The King's College Chapel [Fig 11A: [56]] in Britain and La Sainte Chapel [Fig 11B: [57]] in Paris were the first examples where the concept of fully glazed and clad wall with enlarged windows were developed. In modern high-rise buildings, the exterior walls were suspended from the concrete floor slabs; such as curtain walls, precast concrete walls, massing, etc.
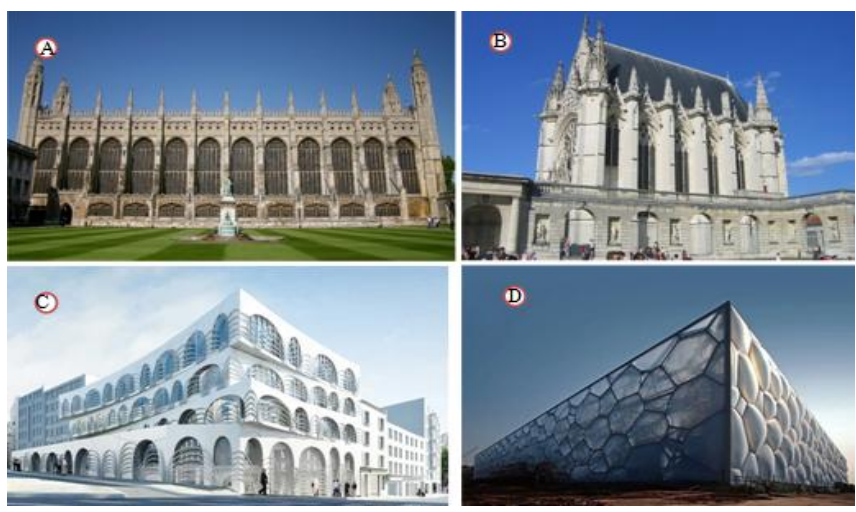

Fig -11: Façades

The façade designs have become more complicated due to the new methods of construction, sustainable requirements, advent of materials and production methods [58]. Today, the digital generative processes open up a new door for conceptual, formal and tectonic explorations articulating an 
architectural morphology focused on the emergent and adaptive properties of form; such as massing [Fig 11C: [59]] [Fig 11D: [60]] on different facades that improvise the aesthetic appearance of the buildings and further creates a unique structure never built before without compromising on the functional aspects.

\subsection{Decorative Interiors}

Many types of art from varied cultures of ancient societies have developed over centuries depicting gods, rulers, inscriptions rendered in regional scripts, pottery, etc. There is a clear transition from bygone antique elements to simplistic or modern art forms; for instance, the cave paintings and handicrafts from the Stone Age; invention of cuneiform script on clay tablets by Mesopotamians; Syllables for writing by Sumerians; hieroglyphic writing and Hebrew language by Egyptians [Fig 12A: [61]]; sculpture, painting, architecture and ceramics by the classical Greek and Romans; Medieval art including Early Christian, Byzantine, Romanesque, Baroque, Rococo and Gothic art; the modern art forms of Abstract illusionism, Digital, virtual, Mural and Graffiti, etc. [62].
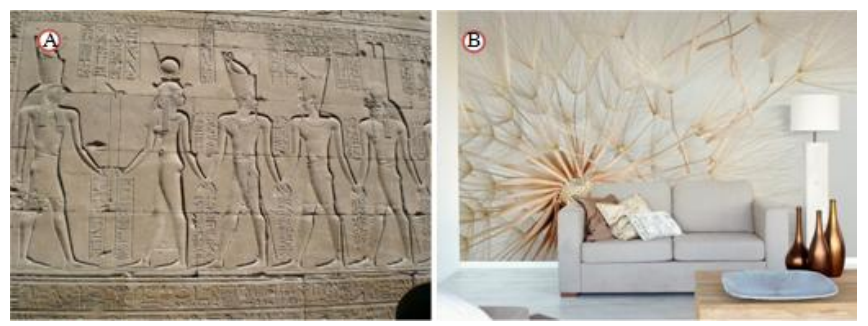

Fig -12: Art in architecture

To support this, we can study the ancient relief art from Egyptian civilization and many modern interior wall mural designs [Fig 12B: [63]].

\section{CONCLUSION}

Preserving the relics of our History of architecture is important for several reasons- they provide an insight into the history of our world and also shows us how people lived their lives many centuries ago. Without the physically existing historical heritage monuments, we could only learn about them by books. Derivations and inferences from the then knowledge base helps in solving contemporary issues in more simple and sustainable way. The architectural history proves and authenticates the futuristic vision of the legendary constructors and builders along with the commitment and excellency in workmanship by the contributors; thus reinforcing its importance and triggering the need of attributing these qualities along with utilization of the technological sophistications. So, without discouraging modernization and compromising on our traditions and customs that are priceless and irreplaceable, this concept of 'historic recurrence' could help in recreating, restoring and further extending the existence of our historical masterpieces and also transferring our ancestral legacy to our future generations, using new and contemporary innovations.

\section{REFERENCES}

[1]. Libeskind, D. (2012). Xplore Inc. Retrieved July 30, 2015, from BrainyQuote: http://www.brainyquote.com

[2]. Gehry, F. (n.d.). Xplore Inc. Retrieved July 30, 2015, from BrainyQuote: http://www.brainyquote.com

[3]. Curl, J. S. (2006). A Dictionary of Architecture and Landscape Architecture. Oxford University Press.

[4]. G.W., T. (1979). The Idea of Historical Recurrence in Western Thought. Berkeley: University of California Press.

[5]. iraq:-the-cradle-of-civilization. (1995). Retrieved july 25, 2015, from www.islamicity.org: http://www.islamicity.org/1975/iraq:-the-cradle-ofcivilization/

[6]. Clayton, P., \& Price, M. (1988). The Hanging Gardens of Babylon. In I. Finkel, The Seven Wonders of the Ancient World (p. 38). New York: Routledge.

[7]. ACROS Fukuoka Final Project. (2010, November 19). Retrieved July 20, 2015, from PB Works: http://caterinabrazzoduro1.pbworks.com

[8]. Edmund, S. C., \& Linda, M. (2010). The Green Roof Manual. Portland: Timber Press.

[9]. Dana, T. (2003, November 15). Towers to the Heavens. Retrieved July 30, 2015, from Newsweek: msnbc.msn.com

[10]. the-tower-of-babel-miguel-rodriguez. (2010, June). Retrieved July 20, 2015, from wordpress.com: wallacegsmith.wordpress.com

[11]. Encyclopedia of countries and cities. (2014). Retrieved July 22, 2015, from Paradise on Earth: http://allworldtowns.com/

[12]. Qutb Minar. (2012, April 4). Retrieved July 12, 2015, from wordpress.com: keepcalmandcurryon.wordpress.com

[13]. Stewart, D. J. (n.d.). The Tower Of Babel Today. Retrieved July 20, 2015, from jesus-is-savior.com: http://www.jesus-is-savior.com

[14]. Leonhardt, F. (1989). Tower. Retrieved July 11, 2015, from Wikimedia Foundation, Inc.: en.wikipedia.org

[15]. A, L. O. (1977). Ancient Mesopotamia. Chicago: University of Chicago Press.

[16]. Fletcher, E. (2006). Bible Study Resource for Archaeology: Babylon and Ziggurats. Retrieved July 13, 2015, from womeninthebible.net: www.biblearchaeology.info

[17]. Zwanzger, S. (2008). Atlantis The Palm. Retrieved July 20, 2015, from The Theme Park Guy \& roller coaster hat: http://www.thethemeparkguy.com/

[18]. Dubai's Best Water Park. (2015). Retrieved July 15, 2015, from Atlantis the palm: atlantisthepalm.com

[19]. Blackwell, P. G., \& Talcott, R. (2006). Stargazing in Ancient Egypt. In Astronomy (pp. 62-67). Egypt.

[20]. Patricia, G. B., \& Talcott, R. (2010, June 6). Stargazing in ancient Egypt. Astronomy Magazine , pp. 62-67.

[21]. Nature-Egyptian Pyramids. (2014, June 24). Retrieved July 20, 2015, from Cool Wallpapers for you: http://wallerz.net

[22]. Lee, E. (2008, August 25). ZIGGURAT: Dubai's Carbon Neutral Pyramid Will House 1 Million. 
Retrieved July 20, 2015, from Inhabitat: http://inhabitat.com

[23]. Soleri, P. (1973). The Bridge Between Matter \& Spirit is Matter Becoming Spirit. In P. Soleri, The Arcology of Paolo Soleri (p. 46). Garden City, NewYork: Anchor Books.

[24]. Gregory, R. L. (1997). Knowledge in perception and illusion. Bristol: Phil. Trans. R. Soc. Lond. B.

[25]. Meisner, G. (2013, January 20). The Parthenon and Phi, the Golden Ratio. Retrieved July 28, 2015, from PhiPoint Solutions,: goldennumber.net

[26]. Mills, J. (2010, July 20). Warrnambool Campus Building by Lyons. Retrieved June 30, 2015, from dezeen magazine: dezeen.com

[27]. Dean, J. (2007, May 12). Melting Building Mural. Retrieved June 30, 2015, from Mighty Optical Illusions: moillusions.com

[28]. Chinneck, A. (2015). Incredible Optical Illusion Makes Building Appear To Float In Mid-Air. Retrieved June 30, 2015, from Fast Company: fastcodesign.com

[29]. GDS, A. (2013, September 16). The World's First Invisible Skyscraper: An Optical Illusion. Retrieved July 30, 2015, from International business times: http://news.filehippo.com

[30]. Bekker, J. (2006, December 23). Architecture inspired by the café wall illusion at Melbourne Docklands. Retrieved July 15, 2015, from the Wikimedia Foundation, Inc.: en.wikipedia.org

[31]. Bomgardner, D. L. (2000). The Story of the Roman Amphitheatre. London: Routledge.

[32]. The Colosseum of Rome . (2011, October 7). Retrieved July 15, 2015, from visits2world: http://visits2world.blogspot.in

[33]. Kristen. (2014, June 16). Beijing National Stadium Second name is Bird's Nest built in March 2003. Retrieved July 21, 2015, from Travellers Adventures: http://www.travellersadventures.com

[34]. Icher, F. (1998). Building the Great Cathedrals. New York: Harry N. Abrams.

[35]. [35] Markus, M. (2009, February 1). Milan Cathedral. Retrieved July 21, 2015, from Wikimedia Foundation, Inc.: en.wikipedia.org

[36]. Nesnad. (2009, September 20). Sagrada Familia. Retrieved July 21, 2015, from Wikimedia Foundation, Inc.: en.wikipedia.org

[37]. Wilkinson, T. (2005). The Thames and Hudson Dictionary of Ancient Egypt. London: Thames \& Hudson.

[38]. Lachish, the doomed city. (n.d.). Retrieved July 23, 2015, from Bible Architecture: bible-architecture.info

[39]. Strzelecki, J. (2007, December 19). Luxor Temple. Retrieved July 30, 2015, from Wikimedia Foundation, Inc.: en.wikipedia.org

[40]. Gandhi, R. (2012, August 5). Ahmedabad/Gandhinagar Cityscapes. Retrieved July 30, 2015, from vBulletin Solutions, Inc.: skyscrapercity.com

[41]. Developer's, S. (2009, January 17). Malwa County, AB By-pass Road Indore. Retrieved July 30, 2015, from 360Reality: 360realty.in

[42]. Stierlin, H. (2004). Greece: From Mycenae to the
Parthenon. Cologne: Taschen.

[43]. G, J. (2013, June 10). Pantheon, Rome. Retrieved July 30, 2015, from Ancient History Encyclopedia: ancient.eu

[44]. Stierlin, H., \& Kinkle, S. (2002). The Roman Empire: From the Etruscans to the Decline of the Roman Empire. Cologne: Taschen.

[45]. Cambridge Sail entrance canopy. (n.d.). Retrieved July 31, 2015, from Building Design: buildingdesignindex.co.uk

[46]. Canopy (building). (2010, July). Retrieved June 28, 2015, from Wikipedia.org: en.wikipedia.org

[47]. Livio, M. (2002). The Golden Ratio: The Story of Phi, The World's Most Astonishing Number. NewYork: Broadway Books.

[48]. Bernhard, P. (2005). Der Goldene Schnitt am Parthenon, Athen. Retrieved June 30, 2015, from drbernhard-peter: dr-bernhard-peter.de

[49]. Nathe, C., \& Hobgood, K. (n.d.). The Golden Ratio and the Great Pyramids. Retrieved July 30, 2015, from Culturefocus.com: http://jwilson.coe.uga.edu

[50]. Obara, S. (n.d.). Golden Ratio in Art and Architecture. Retrieved July 28, 2015, from The University of Georgia (Mathematics Education): http://jwilson.coe.uga.edu

[51]. Gillian, J. R. (n.d.). OCCURRENCES IN THE WORLD AROUND US. Retrieved July 30, 2015, from The Fibonacci Series: odec.ca

[52]. PYONGYANG, Ryugyong Hotel - Reconstruction. (2013, May 11). Retrieved July 25, 2015, from SkyscraperPage.com: http://forum.skyscraperpage.com

[53]. Helms, I. (2010, January 7). Golden ratio discovered in a quantum world. Retrieved June 15, 2015, from EurekAlert: Eurekalert.org

[54]. Oxford English dictionary. (1989). New York: Oxford University Press.

[55]. Fleming, e. a. (1980). The Penguin Dictionary of Architecture.

[56]. Sellers, U. (2009, September 7-13). Travel-Learn Program. Retrieved July 29, 2015, from Tufts Alumni 2015: http://tuftsalumni.org

[57]. Commons, C. (2014, April 22). La Sainte Chapelle du Chateau de Vincennes ancienne demeure royale vers le Bois de Vincennes en France. Retrieved July 31, 2015, from Wikimedia Commons: commons.wikimedia.org

[58]. Knaack, U., Klein, T., Bilow, M., \& Auer, T. (2007). Principles of Construction. Boston/Basel/Berlin: Birkhaüser-Verlag.

[59]. I, L. (2015, June 28). Institute for Islamic Culture, Paris. Retrieved August 1, 2015, from e-architect: earchitect.co.uk

[60]. Kelvin's Conjecture: The Sustainability of Optimization and Integration. (2008, June 23). Retrieved July 28, 2015, from ZIGER/SNEAD: zigersnead.com

[61]. Ancient Egyptian Art and Architecture with Unique Decoration And Architecture Artists. (2015). Retrieved July 28, 2015, from Dictionar: dictionar.co

[62]. Shiner, L. (2003). The Invention of Art: A Cultural History. Chicago: University of Chicago. 
[63]. interior design inspiration- wall murals . (2010, April 12). Retrieved July 27, 2015, from vol25 The Blog: http://vol25.typepad.com

\section{BIOGRAPHIES}

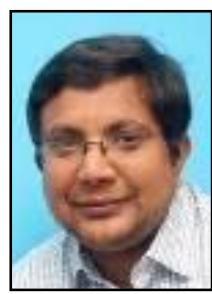

Ar. Ravindra Patnayaka, he is working as Asst. Professor in School of Architecture, GITAM University-Visakhapatnam; previously he has done his Master in Planning at JNAFAU, Hyderabad. His research focuses on integrating Urban Design and Architectural elements through empirical solutions.

Ph.No.+919985503512(or)Email.rpdesigndesk@gmail.com

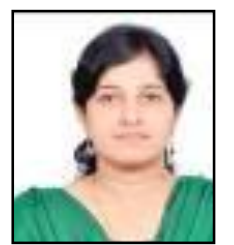

Ar. Suryakala Nannapaneni, she is working as Asst. Professor in School of Architecture, GITAM UniversityVisakhapatnam; previously she has done her Masters in Architecture at Savannah College of Art and Design, Georgia-United States of America. Her research focuses on sustainable aspects of Architecture and Urban Design.Ph. No. +91 9052678363 (or) Email. architectkala@gmail.com 